\title{
INFORME UM CARTAZ EM CADA ESCOLA
}

O Centro Regional de Análise de São Paulo (Sprace), em parceria com docentes e pesquisadores das universidades UNESP e USP e com apoio financeiro da Universidade Federal do ABC (UFABC) e do CNPq, através do projeto "Estrutura Elementar da Matéria: Um Cartaz em Cada Escola", pretende distribuir a todas as 24.131 escolas públicas e privadas de Ensino Médio do Brasil 50 mil cartazes, cerca de dois para cada instituição de ensino, tendo por finalidade aguçar a curiosidade dos jovens e despertar vocações para o estudo das ciências físicas. Serão distribuídos ainda folhetos explicativos para que os professores possam responder às questões levantadas pelos alunos. Cartaz e folheto contêm conhecimentos básicos sobre os constituintes da matéria e as interações que regem o mundo subatômico.

Segundo o físico Sergio Novaes, coordenador do projeto e professor do Instituto de Física Teórica da UNESP, "a idealização do projeto foi motivada pela grande defasagem nos conteúdos ensinados nas escolas sobre a estrutura da matéria, comparado com o avanço do conhecimento adquirido pelas comunidades científicas nacional e internacional".

De acordo com ele, essa defasagem no currículo escolar do Ensino Médio no país, "que praticamente não leva em conta os avanços do século passado", varia de 70 a 100 anos. Os esforços para se descobrir do que a matéria e o Universo são constituídos, no entanto, são muito antigos e foram acompanhados de diversas propostas para sua descrição. "Isso envolve desde as descrições mais simples e que já foram descartadas, como a dos antigos gregos sobre os quatro elementos - terra, fogo, água e ar - até as mais complexas e atuais, feitas após a introdução da tabela periódica por Dmitri Mendeleiev no fim do século XIX. O problema é que o século XX presenciou avanços profundos no conhecimento da estrutura mais íntima da matéria que muitas vezes são completamente ignorados", afirmou. Com as experiências realizadas nos aceleradores de partículas, que foram capazes de ampliar e aprofundar a visão sobre o interior da matéria, hoje se sabe, por exemplo, que os prótons e nêutrons, que compõem o núcleo atômico, são também elementos compostos e com estrutura interna formada por partículas conhecidas como "quarks".

\footnotetext{
${ }^{+}$Retirado do Boletim da Agência Fapesp de 07/03/2008.

Disponível em: <www.agencia.fapesp.br/>.
} 
"Esses conceitos, até onde se sabe, são os mais corretos. Enquanto isso a Física ensinada nas escolas parou na tabela periódica de Mendeleiev".

Mais informações: <www.sprace.org.br/eem> 